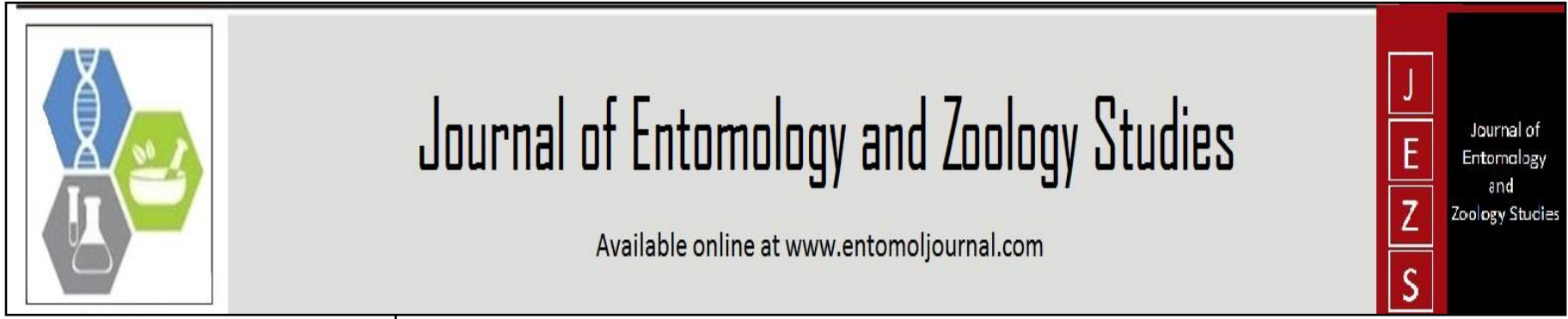

E-ISSN: 2320-7078

P-ISSN: 2349-6800

www.entomoljournal.com JEZS 2021; 9(2): 396-398 (C) $2021 \mathrm{JEZS}$

Received: 27-12-2020

Accepted: 25-02-2021

\section{Sunidhi Pilania}

M.Sc. Entomology, Department of Entomology, College of Agriculture, Chaudhary Charan Singh Haryana Agricultural University, Hisar, Haryana, India

\section{Surender Singh Yadav}

Assistant Director (Plant

Protection), Directorate of

Research, Chaudhary Charan Singh Haryana Agricultural University, Hisar, Haryana, India

\section{Krishna Rolania}

Assistant Scientist, Department of Entomology, College of Agriculture, Chaudhary Charan Singh Haryana Agricultural University, Hisar, Haryana, India

\section{Rakesh Kumar}

District Extension Specialist (Plant Pathology), Agricultural Technology Information Centre, Chaudhary Charan Singh Haryana Agricultural University, Hisar, Haryana, India

\section{Jyoti Indora}

M.Sc. Entomology, Department of Entomology, College of Agriculture, Chaudhary Charan Singh Haryana Agricultural University, Hisar, Haryana, India

\section{Amit Kumar}

M.Sc. Entomology, Department of Entomology, College of Agriculture, Chaudhary Charan Singh Haryana Agricultural University, Hisar, Haryana, India

Corresponding Author: Sunidhi Pilania

M.Sc. Entomology, Department of Entomology, College of Agriculture, Chaudhary Charan Singh Haryana Agricultural University, Hisar, Haryana, India

\section{Assessment of avoidable yield losses in bitter gourd due to melon fruit fly, Bactrocera cucurbitae (Coquillett)}

\author{
Sunidhi Pilania, Surender Singh Yadav, Krishna Rolania, Rakesh Kumar, \\ Jyoti Indora and Amit Kumar
}

DOI: https://doi.org/10.22271/j.ento.2021.v9.i2f.8509

\begin{abstract}
The estimation of crop losses is essential for the scheduling of integrated management tactics as it helps to determine priorities on the basis of relative importance of pests. Cucurbits, the most economically nutritious crops, suffer a quiet high damage by fruit flies. Therefore, the current investigation was carried out to estimate the avoidable yield losses due to melon fruit fly, Bactrocera cucurbitae in the bitter gourd variety 'Pusa Do Mausami'. The study was conducted at Experimental Area, Department of Entomology, Chaudhary Charan Singh Haryana Agricultural University, Hisar during Kharif 2019. The results revealed significant differences in the yields of treated (Malathion 50\% EC@2 ml + jaggery @3 g/litre water) and untreated plots. The average yield of bitter gourd in the untreated plots was 1.57 fold less $(53.72 \mathrm{q} / \mathrm{ha}$ ) compared with $84.24 \mathrm{q} / \mathrm{ha}$ for the treated plots. The calculated avoidable yield loss due to $B$. cucurbitae was 36.24 per cent in bitter gourd.
\end{abstract}

Keywords: Bactrocera cucurbitae, avoidable yield losses, bitter gourd, malathion

\section{Introduction}

In the agro-ecosystems, sustainable agriculture can indefinitely meet the demands for food and fibre at socially acceptable, economic and environment cost. Ultimately, the aim is to develop farming systems that are productive and profitable, conserve the natural resources, protect the environment, and enhance health and safety for a long period of time. Considering these objectives, Integrated Pest Management could be the key for each agro-ecological zone to achieve full yield potential. To schedule the integrated management tactics, information on crop losses is must which determines the relative importance of pests.

Among the cucurbitaceous vegetables, bitter gourd (Momordica charantia L.) is one of the most important and well known vegetable crops cultivated all around the globe. It is a crosspollinated annual, tropical and subtropical vine with inexplicable medical advantages, about the treatment of diabetes ${ }^{[6]}$, dysentery, gout and rheumatism ${ }^{[15]}$ and prevention of breast cancer ${ }^{[11]}$. It is laxative and consumption imparts heating and wormicidal power to the human body. In India, it is cultivated over an area of 99,000 ha with the production of 12.05 lakh MT and productivity of $12.17 \mathrm{MT} / \mathrm{ha}^{[2]}$.

More than a dozen insect pests have been reported to cause varying degrees of damage to bitter gourd crop ${ }^{[16]}$ among which melon fruit fly, (Bactrocera cucurbitae Coquillett) has been reported as the key pest. The two major species, B. cucurbitae and B. tau (Walker) cause a heavy infestation in cucurbits, the former being a major threat ${ }^{[5]}$. About 81 cucurbitaceous vegetables have been reported to get attacked by $B$. cucurbitae, especially bitter gourd, bottle gourd, snake gourd, musk melon, snap melon, ridge gourd and cucumber ${ }^{[3]}$.

The gravid females of $B$. cucurbitae puncture the soft and tender fruits by their sharp ovipositor to lay eggs in fruit tissues and watery fluid oozes from the puncture. Sometimes fruits have also been accounted for punctures without egg (pseudo-punctures), which reduces the market value of the produce ${ }^{[9]}$. Soon after hatching, the maggots feed on the pulp of the fruits by making galleries and then lead to the secondary infection, resulting in rotting of fruits. The melon fruit fly, B. cucurbitae is reported to causes 30.0 to 100.0 per cent losses in cucurbits depending on the host species and season ${ }^{[4,7]}$ reported 95.0 per cent infestation in 
the bitter gourd fruits in New Guinea while 60.0 to 87.0 per cent in pumpkin fruits and 90.0 per cent in snake gourd in the Solomon Islands. However, the fruit infestation of 31.3 and 28.6 per cent was recorded in bitter gourd and water melon, respectively in India by ${ }^{[14]}$ in 2000 . The tremendous increase in pest population during the fruiting stage causes detrimental effects on fruits; thereby making them unfit for consumption and reduce their marketability. Thus, it is necessary to assess the avoidable yield losses which may contribute towards the development of safe, economical and sustainable methods of pest management, as well as food security, for the future. Therefore, the present investigation was conducted to generate location specific information about the amount of damage inflicted on bitter gourd by $B$. cucurbitae which can be avoided using suitable management tactics.

\section{Material and Methods}

The field experiment for the estimation of avoidable losses was carried out at Experimental Area, Department of Entomology, Chaudhary Charan Singh Haryana Agricultural University, Hisar during Kharif 2019 using the variety 'Pusa Do Mausami' of bitter gourd. The experiment was laid out in twenty six plots of size $3 \times 3 \mathrm{~m}^{2}$ with a spacing of $150 \times 45$ $\mathrm{cm}^{2}$ where two treatments viz. treated and untreated, were replicated thirteen times. The treated plots were sprayed with Malathion 50\% EC @ 2 ml + jaggery @ 3 g/litre of water to prevent the losses caused by B. cucurbitae. Healthy and infested fruits were sorted out at each picking.

The yield from these plots was recorded and analysed statistically using the 'paired t' test. Avoidable losses were calculated as per ${ }^{[10]}$ using the following formula:

Avoidable yield loss $(\%)=\frac{\mathrm{T}-\mathrm{C}}{\mathrm{T}} \times 100$
Where,

$\mathrm{T}=$ yield of treated plots $(\mathrm{q} / \mathrm{ha})$

$\mathrm{C}=$ yield of untreated/control plots $(\mathrm{q} / \mathrm{ha})$

\section{Results and Discussion}

The results of the recent study estimated the avoidable yield losses caused by melon fruit fly which are presented in Table 1. It revealed the significant difference between the treated and untreated plots. The average yield of treated and untreated plots was recorded as 84.24 and 53.72 quintals per hectare (q/ha), respectively. The average mean yield difference among treated and untreated plots was recorded as 30.53q/ ha. Accordingly, the untreated plots fetched 1.57 times lower yield and the avoidable yield loss on the basis of difference in yield among treated and untreated plots was 36.24 per cent.

These results are in agreement with those of [1] who reported the yield loss of 35.48 and 37.16 per cent in bitter gourd and bottle gourd, respectively due to melon fruit fly and further revealed 1.55 and 1.58 fold increase in yield of bitter gourd and bottle gourd fruits in Malathion $(0.1 \%)$ treated plots compared to untreated control plots. Congruous with the current findings ${ }^{[8]}$, estimated the avoidable loss of 38.69 per cent in cucumber due to $B$. cucurbitae, when the plants were treated with Fenthion $(0.1 \%)$ and Malathion (0.1\%) alternatively starting from fruit formation to fruit maturity ${ }^{[12]}$. estimated the avoidable yield loss of $41.67 \%$ in cucumber due to the attack of $B$. cucurbitae when treated with Malathion $(0.1 \%)$. Their findings also revealed that the yield in untreated plots was 1.71 times lower than the Malathion $(0.1 \%)$ treated plots. From the findings of ${ }^{[5]}$ it can also be concluded that the treatment of Malathion 50\% EC + jaggery to bitter gourd plants against melon fruit fly accounted for 1.61 times more yield than untreated (control) plots ${ }^{[13]}$. Reported the highest per cent avoidable yield loss $(49.02 \%)$ in cucumber treated with Spinosad 45SC.

Table 1: Avoidable yield loss caused by Bactrocera cucurbitae in bitter gourd during Kharif 2019

\begin{tabular}{|c|c|c|c|c|c|c|c|c|}
\hline & \multicolumn{2}{|c|}{ Yield (q/ha) } & \multirow{2}{*}{ Difference } & \multirow{2}{*}{$\begin{array}{l}\text { Deviation from } \\
\text { mean }(d)\end{array}$} & \multirow{2}{*}{$\begin{array}{c}\text { Square of } \\
\text { deviation }\left(d^{2}\right)\end{array}$} & \multicolumn{2}{|c|}{$\begin{array}{c}\text { Value of } \mathrm{T} \text { at } 5 \% \text { level of } \\
\text { significance }\end{array}$} & \multirow{2}{*}{$\begin{array}{l}\text { Avoidable yield } \\
\text { loss }(\%)\end{array}$} \\
\hline Replications & Treated & Untreated & & & & Calculated & Tabulated & \\
\hline 1 & 86.14 & 53.64 & 32.50 & -1.97 & 3.90 & \multirow{13}{*}{$78.78 *$} & \multirow{13}{*}{1.78} & \multirow{13}{*}{36.24} \\
\hline 2 & 81.37 & 51.62 & 29.75 & 0.78 & 0.60 & & & \\
\hline 3 & 85.01 & 52.24 & 32.77 & -2.24 & 5.03 & & & \\
\hline 4 & 83.47 & 54.31 & 29.16 & 1.37 & 1.87 & & & \\
\hline 5 & 84.82 & 54.31 & 30.51 & 0.02 & 0.00 & & & \\
\hline 6 & 85.53 & 52.63 & 32.90 & -2.37 & 5.64 & & & \\
\hline 7 & 81.62 & 52.88 & 28.74 & 1.79 & 3.19 & & & \\
\hline 8 & 86.54 & 56.49 & 30.05 & 0.48 & 0.23 & & & \\
\hline 9 & 85.61 & 54.87 & 30.74 & -0.21 & 0.05 & & & \\
\hline 10 & 86.35 & 57.25 & 29.1 & 1.43 & 2.03 & & & \\
\hline 11 & 84.96 & 54.78 & 30.18 & 0.35 & 0.12 & & & \\
\hline 12 & 83.89 & 53.13 & 30.76 & -0.23 & 0.05 & & & \\
\hline \multirow[t]{2}{*}{13} & 79.86 & 50.18 & 29.68 & 0.85 & 0.72 & & & \\
\hline & 84.24 & 53.72 & 30.53 & & 23.42 & & & \\
\hline
\end{tabular}

\section{Conclusion}

In the present investigation, the bitter gourd crop (Pusa Do Mausami) suffered a significant reduction in yield due to the infestation of B. cucurbitae. The average yield of bitter gourd in the untreated plots was 1.57 folds less (53.72 q/ha) compared with $84.24 \mathrm{q} /$ ha for Malathion 50\% EC @ $2 \mathrm{ml}+$ jaggery@3 g/litre treated plots. A significant difference of $30.53 \mathrm{q} / \mathrm{ha}$ was reported in treated and untreated conditions. The avoidable yield loss of 36.24 per cent was estimated in bitter gourd due to $B$. cucurbitae.

\section{Acknowledgement}

The authors highly obliged to Head, Department of Entomology, Chaudhary Charan Singh Haryana Agricultural University, Hisar for the provision of necessary facilities, valuable suggestions and encouragement for the current investigation. 


\section{References}

1. Abrol D. Evaluation of some insecticides, biopesticides and clay for the management of fruit fly, Bactrocera spp. infesting bitter gourd and bottle gourd. Ph.D. thesis, Dr. Y. S. Parmar University of Horticulture \& Forestry, Nauni, Himachal Pradesh 2017.

2. Anonymous. $2^{\text {nd }}$ Advance Estimate of 2019-20 of Horticulture Crops. Ministry of Agriculture \& Farmers Welfare, Govt. of India. (https://pib.gov.in/Pressreleaseshare.aspx?PRID=162869 5) Accessed on 26 August, 2020.

3. Anonymous. Integrated management of cucurbit fruit fly, Bactrocera cucurbitae (Coquillett) in Bangladesh. IPM CRSP Bangladesh site technical bulletin no. 1, 2004.

4. Dhillon MK, Singh R, Naresh JS, Sharma HC. The melon fruit fly, Bactrocera cucurbitae: A review of its biology and management. Journal of Insect Science. 2005; 40(1):1-16.

5. Gaddanakeri SV. Biology, biometrics and management of melon fruit fly, Bactrocera cucurbitae (Coq.) on bitter gourd, Momordica charantia L. M.Sc. thesis, College of Agriculture, CCS HAU, Hisar, Haryana, 2019.

6. Grover JK, Yadav S, Vats V. Medicinal plants of India with anti-diabetic potential. Journal of Ethnopharmacology 2002;81:81-100.

7. Hollingsworth RG, Vagalo M, Tsatsia F. Biology of melon fly, with special reference to Solomon Islands. In ACIAR Proceedings. Australian Centre for International Agricultural Research 1997, 140-144,

8. Kate AO, Bharodia RK, Joshi MD, Pardeshi AM, Makadia RR. Estimation on yield losses in cucumber due to fruit fly, Bactrocera cucurbitae (Coquillet). International Journal of Plant Protection 2009;2(2):276277.

9. Khursheed S, Raj D. Bio-efficacy of certain insecticides and biopesticides against melon fruit flies, Bactrocera spp. Pest Management in Horticultural Ecosystems 2012;18(2):143-148.

10. Pradhan S. Insect Pests of Crops. National Book Trust. New Delhi, India 1969, 80.

11. Ray RB, Raychoudhuri A, Steele R, Nerurkar P. Bitter melon (Momordica charantia) extract inhibits breast cancer cell proliferation by modulating cell cycle regulatory genes and promotes apoptosis. Cancer Research 2010;70:1925-1931.

12. Sharma N, Gupta D. Evaluation of some new insecticides molecules for the management of fruit fly, Bactrocera spp. infesting cucumber. Journal of Entomology and Zoology Studies 2019;7(6):1172-1175.

13. Shivangi, Lekha, Swami H. Bio-intensive management of fruit fly, Bactrocera cucurbitae (Coquillett.) in cucumber. Journal of Entomology and Zoology Studies 2017;5(3):1823-1826.

14. Singh SV, Mishra A, Bisen RS, Malik YP, Mishra A. Host preference of red pumpkin beetle, Aulacophora foveicollis and melon fruit fly, Bactrocera cucurbitae. Indian Journal of Entomology 2000;62(3):242-246.

15. Subratty AH, Gurib-Fakim A, Mabomoodally F. Bitter melon: An exotic vegetable with medicinal values. Nutrition and Food Science 2005;35:143-147.

16. Thippaiah SM, Jayaram CS. Population estimation and seasonal incidence of minor insect pests of bitter gourd (Momordica charantia L.). Environment and Ecology 2017;35(2):724-729. 